\title{
Evaluation of the Learning Environment at the Faculty of Medicine, Suez Canal University: Students' Perceptions
}

Wagdy Talaat Youssef, Yasser Mohamed EI Wazir, Mona Sayed Ghaly and Rania Aly El Khadragy*

Faculty of Medicine, Suez Canal University, Egypt

\begin{abstract}
Aim: This study aimed at evaluating the learning environment among undergraduate medical students at the Faculty of Medicine, Suez Canal University, and recommending remedial measures for further enhancement of students' learning experiences.

Methodology: The study was a descriptive, cross sectional study. The target population included the undergraduate students from year 1 to year 6 during the academic year (2009-2010). The sample size was 316 students (sample size was originally estimated 326; students' response rate was 96.9\%). The instrument used in this study was The Dundee Ready Education Environment Measure (DREEM) questionnaire which is a validated and reliable tool. The 50 items of the questionnaire encompasses five subscales: perceptions of learning, perceptions of teachers (course organizers), academic self-perceptions, perceptions of atmosphere and social self-perceptions.

Results: After evaluation of all DREEM questionnaires, the total score of all six years was 113.8 which was interpreted according to the practical guide of McAleer and Roff that students' perceptions of their learning environment were more positive than negative. The score for all the five subscales of DREEM indicated a more positive perception except for subscale 5 (social self perception).

Conclusion: The study concluded that students throughout the different years of study perceived the learning environment positively. Nevertheless, the study also revealed problematic areas in some items which enabled us to adopt some remedial measures.
\end{abstract}

Keywords: Learning Environment; Climate; Curriculum; Student Satisfaction; DREEM Model

\section{Introduction}

Curriculum is considered to be the most holistic, inclusive and comprehensive entity in education. This aspect of holism and comprehensiveness leads one to define curriculum as everything that is happening in the classroom, department, faculty, medical school or the university as a whole [1].

Curriculum's most significant manifestation and conceptualization is the educational and organizational environment, which embraces everything that is happening in the medical school. There is a proven connection between the environment and the outcomes of students' achievement, satisfaction and success [2].

The General Medical Council (GMC) in U.K. has initiated major innovations in the undergraduate medical curriculum and improvement of the learning environment is one of the major goals of these innovations [3]. The World Federation for Medical Education (WFME) considers the learning environment as one of the areas that should be targeted when evaluating medical education programs [4].

The Faculty of Medicine-Suez Canal University (FOM-SCU) was established in 1976 to become the first problem- based, community oriented/based and student-centered school in the Middle East. The main objective of its establishment was to meet the health needs of the five Suez Canal governorates (Ismailia, Port Said, Suez, North and South Sinai) [5].

As educational Environment strongly affects student achievement, satisfaction and success, it is important to get feedback from our undergraduate students on how they experience the educational environment at FOM-SCU. Although a complex array of personal and professional factors influence student well-being, student satisfaction with specific characteristics of the learning environment remains to be a critical factor.

Therefore, this study can provide a useful basis for strategic planning and resource utilization. Results will provide guidance to institutional remedial action regarding students' indication of areas of concern.

\section{What is a learning environment?}

Bloom described the educational or learning environment concept as "the conditions, forces, and external stimuli which challenge on the individual. These forces may be physical, social, as well as intellectual forces and conditions". He conceived a range of environments from the most immediate social interactions to the more remote cultural and institutional forces. He regarded the environment as providing a network of "forces and factors which surround, engulf, and play on the individual" [6]

Genn defined the learning environment as “the curriculum's most significant manifestation and conceptualization, educational and organizational, which embraces everything that is happening in the medical school". The environment of the medical school is notable, not only because it derives from and is a manifestation of the curriculum,

*Corresponding author: Rania Aly El Khadragy, Assistant Lecturer, Medical Education Department, Faculty of Medicine, Suez Canal University, Egypt, Tel: 00201005107568; E-mail: drraniamed@gmail.com

Received May 08, 2013; Accepted June 24, 2013; Published June 26, 2013

Citation: Youssef WT, Wazir YME, Ghaly MS, Khadragy RAE (2013) Evaluation of the Learning Environment at the Faculty of Medicine, Suez Canal University: Students' Perceptions. Intel Prop Rights 1: 102. doi:10.4172/2375-4516.1000102

Copyright: (c) 2013 Youssef WT, et al. This is an open-access article distributed under the terms of the Creative Commons Attribution License, which permits unrestricted use, distribution, and reproduction in any medium, provided the original author and source are credited. 
Citation: Youssef WT, Wazir YME, Ghaly MS, Khadragy RAE (2013) Evaluation of the Learning Environment at the Faculty of Medicine, Suez Canal University: Students' Perceptions. Intel Prop Rights 1: 102. doi:10.4172/2375-4516.1000102

Page 2 of 7

but also because the environment is a determinant of the behavior of the medical school's students and teachers [2].

Pace and Stern suggested that learning environment is characterized by the pressures, stresses, practices, policies, rewards and values within the classroom or school of which they refer to as 'environmental press'. This term is largely identical with that of climate [7]. Furthermore, one of the 10 questions to be asked when planning a course or curriculum is what educational environment or climate should be fostered? [8].

In many instances, the terms environment and climate are synonymous. They are often used interchangeably in educational literature [9].

Whatever the term environment or 'climate', 'ethos', 'ambiance' and 'atmosphere' of an institution, it is the environment experienced or perceived by students and teachers. Individual students and teachers will respond differently to these subtle elements in their learning experience [8].

\section{Influences of environments on curricula, students and vice versa}

Numerous studies document that students in schools with a better school climate have higher achievement and better socio-emotional health. A caring school climate is associated with [10]:

1. Higher grades, engagement, attendance, expectations and aspirations, a sense of scholastic competence, fewer schools suspensions, and on-time progression through grades

2. Higher self-esteem and self-concept

3. Less anxiety, depression and loneliness

4. Less substance abuse

There is a proven connection between the environment and the outcomes of students' achievement, satisfaction and success. It is important to get regular feedback from students on how they experience the learning environment. Information obtained will provide a useful basis for strategic planning and resource utilization for further improvement [9]

Educational environment research has shown that there is a high price to be paid for a dysfunctional learning environment. The adverse effects include stress, academic failure and dropout, and the cultivation of undesirable behaviors and attitudes. On the other hand, the potential benefits of an enhanced educational environment include comfort, confidence, responsibility, skills, knowledge, reinforcement, learning opportunities and models for practice [9].

\section{Measurement of educational environments}

Climate measures can be used in different modes with the same stakeholders. For example, students may be asked to report, first, their perceptions of the actual environment they have experienced and, second, to report on their ideal or preferred environment. The same climate index can be used with different stakeholders giving, for example, staff and student comparisons [2].

College Characteristics Index (CCI) is the first systematic measuring instrument (Table 1) for college environments, was developed by Pace and Stern to measure college "press" (the environmental pressures that students perceive to be exerted by a given school) Student performance was seen as a function of the congruence between college press and student need (measured by a parallel instrument, the Activities Index, or AI). The theory behind these instruments originated with Murray, who hypothesized that persons respond differently to environmental features (or press) according to their individual needs $[7,11]$.

A quantitative measurement of the educational environment requires the use of an inventory or instrument. The selection of such an instrument should be based on psychometric features, usually come under two main headings, which are validity and reliability. A valid and reliable learning environment tool allows a meaningful measure of the learning environment of an institution, and thus appropriate measures to improve the environment can be taken. In any measurement process,

\begin{tabular}{|c|c|c|}
\hline $\mathrm{N}$ & Instrument/Inventory & Setting \\
\hline 1 & $\begin{array}{l}\text { Medical School Learning Environment } \\
\text { Survey - modified (MSLES) }\end{array}$ & Medicine \\
\hline 2 & Learning Environment Questionnaire (LEQ) & Medicine \\
\hline 3 & Questionnaire from Parry et al. Medicine & Medicine \\
\hline 4 & $\begin{array}{l}\text { Veteran Affairs (VA) learners' perceptions } \\
\text { survey }\end{array}$ & $\begin{array}{l}\text { Medicine(postgraduate, } \\
\text { PG) }\end{array}$ \\
\hline 5 & Learning Environment Assessment (LEA) & Medicine(PG) \\
\hline 6 & $\begin{array}{l}\text { Medical School Environment Questionnaire } \\
\text { (MSEQ) }\end{array}$ & Medicine \\
\hline 7 & Questionnaire from Robins et al. & Medicine \\
\hline 8 & $\begin{array}{l}\text { Medical School Environment Inventory } \\
\text { (MSEI) }\end{array}$ & Medicine \\
\hline 9 & Questionnaire from Rotem, Godwin and Du & Medicine (PG) \\
\hline 10 & Course Valuing Inventory (CVI) & Medicine \\
\hline 11 & $\begin{array}{l}\text { DREEM (Dundee Ready Educational } \\
\text { Environment Measure) }\end{array}$ & $\begin{array}{l}\text { Medicine(undergraduate } \\
\text { and PG), nursing, Dental } \\
\text { and chiropractic }\end{array}$ \\
\hline 12 & $\begin{array}{l}\text { Operating Room Educational Environment } \\
\text { Measure (OREEM) }\end{array}$ & Medicine (PG) \\
\hline 13 & Instrument from Pololi and Price & Medicine \\
\hline 14 & $\begin{array}{l}\text { Surgical Theatre Educational Environment } \\
\text { Measure (STEEM) }\end{array}$ & $\begin{array}{l}\text { Medicine (undergraduate } \\
\text { and PG) }\end{array}$ \\
\hline 15 & $\begin{array}{l}\text { Anesthetic Theatre Educational Environment } \\
\text { Measure (ATEEM) }\end{array}$ & Medicine (PG) \\
\hline 16 & $\begin{array}{l}\text { Practice-Based Educational Environment } \\
\text { Measure }\end{array}$ & Medicine (PG) \\
\hline 17 & $\begin{array}{l}\text { Postgraduate Hospital Educational } \\
\text { Environment measure (PHEEM) }\end{array}$ & Medicine (PG) \\
\hline 18 & Questionnaire from Patel and Dauphinee & Medicine \\
\hline 19 & $\begin{array}{l}\text { Learning Climate Measure from } \\
\text { Wangsaturaka }\end{array}$ & Medicine \\
\hline 20 & Questionnaire from Orton & Modified Nursing \\
\hline 21 & Questionnaire from Hart and Rotem & Nursing \\
\hline 22 & Clinical Learning Environment scale (CLE) & Nursing \\
\hline 23 & $\begin{array}{l}\text { Clinical Learning Environment Inventory } \\
\text { (CLEI) }\end{array}$ & Nursing \\
\hline 24 & $\begin{array}{l}\text { College and University Classroom } \\
\text { Environment Inventory (CUCEI) }\end{array}$ & Nursing \\
\hline 25 & $\begin{array}{l}\text { Clinical Learning Environment and } \\
\text { Supervision (CLES) }\end{array}$ & Nursing \\
\hline 26 & $\begin{array}{l}\text { Clinical Post-Conference Learning } \\
\text { Environment survey (CPCLES) }\end{array}$ & Nursing \\
\hline 27 & $\begin{array}{l}\text { Questionnaire from Gerzina, McLean and } \\
\text { Fairley }\end{array}$ & Dentistry \\
\hline 28 & Learning Environment Survey (LES) & Dentistry \\
\hline 29 & $\begin{array}{l}\text { Clinical Education Instructional Quality } \\
\text { (ClinEd IQ) }\end{array}$ & Dentistry \\
\hline 30 & $\begin{array}{l}\text { Dental Student Learning Environment } \\
\text { Survey (DSLES) }\end{array}$ & Dentistry \\
\hline 31 & $\begin{array}{l}\text { Postgraduate Research Experience } \\
\text { Questionnaire (PREQ) }\end{array}$ & Nursing \\
\hline
\end{tabular}

Table 1: Undergraduate and postgraduate health profession educational environment measurement instruments [10]. 
Citation: Youssef WT, Wazir YME, Ghaly MS, Khadragy RAE (2013) Evaluation of the Learning Environment at the Faculty of Medicine, Suez Canal University: Students' Perceptions. Intel Prop Rights 1: 102. doi:10.4172/2375-4516.1000102

validity refers to whether the instrument or inventory measures what it is supposed to measure; while reliability deals with the reproducibility of the measurement or assessment results. A result may be reliable over different periods of time, over different raters or over different samples of questions [10].

\section{Methods}

A cross sectional descriptive study was conducted to evaluate the learning environment at the Faculty of Medicine, Suez Canal University regarding undergraduate students' perceptions.

The Study population included the undergraduate students from year 1 to year 6 . The study population was selected by stratified random sample. Students were divided into strata according to years of study (16 ), and then students were selected from each year through systematic random technique according to their percent of the target population. Finally, study population was selected using random tables.

The study population consisted of 316 students (sample size was originally estimated as 326 and the response rate was $96.9 \%$ ). The instrument used in this study is The Dundee Ready Education Environment Measure (DREEM) questionnaire.

The English version was used with slight modifications in order to make it easier to our students to clearly understand the meanings of all items.

The validation of the 50-item Dundee Ready Education Environment Measure (DREEM) has been reported. Each item is scored $4-0$ with $4=$ strongly agree, $3=$ Agree, $2=$ Unsure, $1=$ Disagree and $0=$ strongly disagree by the respondents. Nine of the 50 items (numbers $4,8,9,17,25,35,39,48$, and 50) are scored in reverse for analysis (negative items). The inventory encompasses five subscales (Table 2) [12].

Perceptions of learning- 12 items/ maximum score 48, Perceptions of teachers-11 items/maximum score 44, Academic self-perceptions- 8 items/maximum score 32, Perceptions of atmosphere-12 items/ maximum score 48, Social self-perceptions-7 items/maximum score 28.

The DREEM can be used to pinpoint more specific strengths and weaknesses. Items that have a mean score of 3.5 or more are real positive points. Any item with a mean of 2 or less should be examined more closely as they indicate problem areas. Items with a mean of 2-3 are aspects of the climate that could be enhanced.

DREEM has universal face validity in administrations of the DREEM questionnaire throughout the world including via translations into Chinese, Arabic, Portuguese and Spanish among other languages [13]. The instrument has also shown a consistently high reliability in a variety of settings. Internal consistency coefficient Alpha was 0.92 . Alpha coefficients of the questionnaire and its subscales indicate that the instrument and its scales have adequate reliability for measurement [14].

\section{Results}

The distribution of students in each year of study was as follows year 1 students representing $15.3 \%$, year 2 representing $14.1 \%$, year 3 representing $18.1 \%$, year 4 representing $16.5 \%$, year 5 representing $15.6 \%$, and year 6 representing $17.1 \% .106$ males (34\%) and 210 females (66\%) have participated in this study.

After evaluation of all DREEM questionnaires, the total score of all six years was 113.8 along the scale from $0-200$ which was interpreted as more positive than negative learning environment.

Table 3 shows the interpretation of DREEM subscales mean scores for students from all years. The interpretation of the five subscales revealed a perception which is directed more towards the positive side except for subscale 5 (social self perception) with a mean score of 14.2 which is interpreted as the social environment is not a nice place.

Regarding the evaluation of the total DREEM score and subscales among the six years of study, year 1 represented the highest value for the total score (116.5) while year 3 represented the lowest value (111.1). Comparison of the six years using ANOVA revealed that /there was no statistically significant difference between the different years for the five subscales except for subscale 4 (perception of atmosphere) Subsequent post hoc test (least significant differences) revealed that there were statistically significant differences regarding subscale 4 in between (year 1 and year 3), (year 3 and year 4), (year 3 and year 6) where $\mathrm{P}<0.05$.

\section{Evaluation of the total DREEM score and subscales between males and females}

Figure 1 shows the total DREEM scores for both males and females, where females show a mean score of 114.5 and males 112.5 . Both scores have the same interpretation a more positive than negative environment.

\begin{tabular}{|c|c|c|}
\hline Subscale & $\begin{array}{c}\text { Mean } \pm \text { Standard } \\
\text { Deviation }\end{array}$ & Interpretation \\
\hline Perceptions of learning & $28.2 \pm 5.2$ & A more positive perception \\
\hline $\begin{array}{c}\text { Perceptions of course } \\
\text { organizers }\end{array}$ & $25.9 \pm 5.0$ & \begin{tabular}{c} 
Moving in the right direction \\
\hline Academic self-perceptions
\end{tabular} \\
\hline Perceptions of atmosphere & $26.3 \pm 6.2$ & A more positive attitude \\
\hline Social self-perceptions & $14.2 \pm 4.0$ & Not a nice place \\
\hline
\end{tabular}

Table 2: The interpretation of DREEM subscales mean score for students of al six years.

\begin{tabular}{|c|c|c|c|}
\hline Subscale & $\begin{array}{c}\text { Pre-clinical } \\
\text { students } \\
\text { (years1-3) } \\
(\mathrm{N}=155)\end{array}$ & $\begin{array}{c}\text { Clinical students } \\
\text { (years 4-6) } \\
(\mathrm{N}=161)\end{array}$ & $P$ value (t-test) \\
\hline $\begin{array}{l}\text { Subscale } 1 \\
\text { Perception of Learning } \\
\text { (Max 48) }\end{array}$ & $\begin{array}{l}28.3 \\
(5.6)\end{array}$ & $\begin{array}{l}28.2 \\
(4.7)\end{array}$ & 0.85 \\
\hline $\begin{array}{l}\text { Subscale } 2 \\
\text { Perceptions of course } \\
\text { organizers } \\
\text { (Max 44) }\end{array}$ & $\begin{array}{l}25.6 \\
(4.9)\end{array}$ & $\begin{array}{l}26.2 \\
(5.1)\end{array}$ & 0.16 \\
\hline $\begin{array}{l}\text { Subscale } 3 \\
\text { Perceptions of Academic } \\
\text { Achievement } \\
\text { (Max 32) }\end{array}$ & $\begin{array}{l}19.1 \\
(4.3)\end{array}$ & $\begin{array}{l}19.5 \\
(4.2)\end{array}$ & 0.30 \\
\hline $\begin{array}{l}\text { Subscale } 4 \\
\text { Perception of Atmosphere } \\
\text { (Max 48) }\end{array}$ & $\begin{array}{l}25.7 \\
(6.5)\end{array}$ & $\begin{array}{l}26.9 \\
(5.8)\end{array}$ & 0.09 \\
\hline $\begin{array}{l}\text { Subscale } 5 \\
\text { Perceptions of Social } \\
\text { Environment } \\
\text { (Max 22) }\end{array}$ & $\begin{array}{l}14.8 \\
(3.9)\end{array}$ & $\begin{array}{l}13.5 \\
(4.1)\end{array}$ & $0.02^{*}$ \\
\hline $\begin{array}{l}\text { Overall total DREEM } \\
\text { (Max 200) }\end{array}$ & $\begin{array}{l}113.5 \\
(20.3)\end{array}$ & $\begin{array}{l}114.2 \\
(19.1)\end{array}$ & 0.5 \\
\hline
\end{tabular}

*Statistically significant at $\mathrm{P} \leq 0.05$

Table 3: Total and subscale mean (SD) scores of pre-clinical and clinical years of study. 


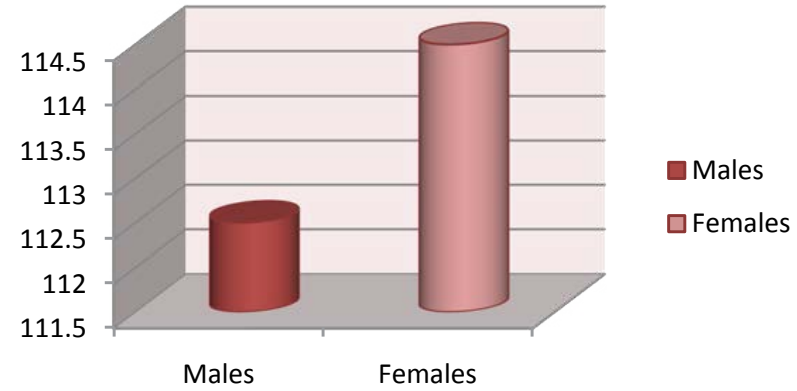

Figure 1: Shows the Total DREEM Scores for both Males and Females.

\section{Evaluation of the total DREEM score and subscales between pre-clinical and clinical years of study}

Table 3 shows the total and subscales mean scores between preclinical and clinical students where clinical students (4-6) show the highest score for total DREEM score and subscales 2, 3 and 4 while pre-clinical students show the highest score for subscales 1 and 5 . T Test shows significant relation in subscale 5 (perception of social environment) between pre-clinical and clinical students $(\mathrm{P} \leq 0.05)$

\section{Evaluation of individual items scores for the total DREEM questionnaire}

The mean of individual items for the five subscales reveals that no single item scored more than 3.5 mean score and this indicates that there are not real positive items. The majority of items' mean scores are between 2 and 3 and this indicates that they could be enhanced. 12 items' mean scores are below 2 and this indicates that they are real problematic areas and need to be examined more closely.

Table 4 shows the mean of items which showed statistically significant differences between males and females students, where $(\mathrm{P} \leq 0.05)$. Out of the 4 items, 2 items (3 and 14) were from Students' Perceptions of atmosphere, 1 item (5) from Students' academic selfperceptions and the last item (32) from Students' perceptions of teachers.

Table 5 shows the mean of items which showed statistically significant differences between pre -clinical and clinical students, where $(P \leq 0.05)$.Out of the 9 items, 2 items $(1$ and 21$)$ were from students' perceptions of learning, 1 item (6) from Students' Perceptions of Teachers, 1 item (31) from Students' Academic Self-Perceptions, 3 items $(12,17$ and 50) from students perception of atmosphere and the last 2 items ( 3 and 15) from students social self-perception.

\section{Discussion}

There has been growing interest and concern about the role of the learning environment in medical education. Learning environment is one of the most important factors in determining the success of an effective curriculum [15]

According to Genn, Curriculum generates and establishes environment, and changes in curriculum are thus essentially changes in environments. The curriculum change was expected to build up a better learning environment, perceived as good by students [2]. A continuous improvement in this environment is only possible by defining its weaknesses and strengths [16].

Students were interested in completing the inventory as evidenced by the good response rate (96.9\%). The response rate in other similar studies ranged from $44.6 \%$ to $95 \%$. This showed that our response rate was the highest indicating that our students were keen to participate in such study to improve their school. This response rate is comparable to that obtained in King Abdul Aziz University (95\%) [17]. On the other hand, the lowest response rate obtained in King Saud University (44.6\%) was explained by students' fears of participation in their study and its impact on their exam results (as a reflection of the authoritarian atmosphere in the school which was evidenced by the lower DREEM score 89.9) [16]. In contrast, the highest response rate obtained in our study was due to the encouraged brief introduction given to students about the aim of this study that leads them to think that the results of such study would lead to significant changes in their learning.

To the best of our knowledge, the evaluation of the learning environments using the DREEM questionnaire appeared in the literature about 35 times, total score ranged from 89.9 to 142.8 over 200 . Out of which 28 studies were directed to medical students' evaluation of their learning environment.

The results presented herein revealed DREEM overall mean score for our medical school of $113.8(\mathrm{n}=316)$. According to the practical guide of McAleer and Roff [17], a mean score between 100 and 150 indicates that students' perceptions of their learning environment were more positive than negative.

Our DREEM overall mean score was higher than that reported for medical schools in Faculty of Medical Sciences, Trinidad (109.9) [18], Srilanka (108) [19], India (107.44) [20], King Faisal Medical School Saudi Arabia (111) [21], Umm Al-Qura University (107) [16], King Abdul Aziz University Saudi Arabia (102) [17], Sana'a University (100) [17], Al-Yemen University (99) [22], Canadian Memorial Chiropractic College (97) [23], King Saud University (89.9) [24].

On the other hand, our overall DREEM score was less than that reported for other medical schools, for example Nigerian Undergraduate Medical School (118) [24] United Arab of Emirates University (UAE) (125) [21], Arab Gulf University in Bahrain(AGU) (127) [21], Nepalese Medical School (130) [24],and Dundee Medical School (139) [25] and the highest mean DREEM score was recorded by Miles and Leinster in UK (142.9) [26].

Many factors might explain this range of differences. First, the educational strategies themselves as our results indicate that the educational environment in PBL schools is superior to those who apply conventional educational strategies. This might be attributed to the fact that in student-centered curricula, students are supposed to be more empowered and thus relatively have more responsibility and control of their learning environments [17]. The second factor that might explain these differences is the variability in students' admission criteria to medical schools and students' expectations of the learning environment in their schools. Also, the cultural perceptions can logically modify response of students in some subscales. Finally, the different applied DREEM versions might also considered being a factor explaining these differences

In our study, the interpretation of the five subscales of DREEM revealed a perception which was directed more towards the positive side, except for subscale 5 (social self perception); with a mean score of 14.2; which was interpreted as the social environment was not a nice place. Also, College of Medicine, King Saud University reported that students' social self-perception subscale was the lowest with a mean score of 13/28 [23]. These findings were concordant with the results reported by the majority of similar studies(e.g. in Nigerian medical 


\begin{tabular}{|c|c|c|c|c|}
\hline & Item & Males & Females & $P$ Value $(P \leq 0.05)$ \\
\hline 3 & There is a good support system for students who get stressed & 1.70 & 1.91 & 0.019 \\
\hline 5 & Learning strategies , which worked for students before ,continue to work for them now & 2.48 & 2.31 & 0.013 \\
\hline 14 & Students are rarely bored on the course & 1.42 & 1.73 & 0.002 \\
\hline 32 & The course organizers provide constructive criticism here & 2.14 & 2.49 & 0.019 \\
\hline
\end{tabular}

Table 4: Mean DREEM Inventory items where significant differences were observed between males and females.

\begin{tabular}{|c|c|c|c|c|}
\hline \multicolumn{2}{|r|}{ Item } & Pre-clinical & Clinical & $P$ Value $(P \leq 0.05)$ \\
\hline 1 & Students are encouraged to participate in teaching $\backslash$ learning sessions & 2.74 & 3.04 & 0.001 \\
\hline 3 & There is a good support system for students who get stressed & 2.02 & 1.68 & 0.022 \\
\hline 6 & The course organizers adopt a patient centered approach to consulting & 2.48 & 2.73 & 0.020 \\
\hline 12 & The course is well timetabled & 2.26 & 2.47 & 0.046 \\
\hline 15 & Students have time to have good friends on this course & 2.69 & 2.37 & 0.007 \\
\hline 17 & Cheating is a problem on this course & 1.61 & 1.87 & 0.048 \\
\hline 21 & Students are well prepared for their profession & 2.31 & 1.96 & 0.006 \\
\hline 31 & Students have learnt a lot about empathy in their profession & 2.54 & 2.75 & 0.020 \\
\hline 50 & The students irritate the course organizers & 1.71 & 2.26 & 0.00 \\
\hline
\end{tabular}

Table 5: Mean DREEM Inventory items where significant differences were observed between pre-clinical and clinical students.

school and Faculty of Medical Sciences, Trinidad) in that the lowest marks were given to the subscales, students' perceptions of atmosphere and social self-perceptions whereas in Nepal and in the UK academic self-perceptions were rated worst [24]. These findings coincided also with the findings of Al Hazimi and others [27]. Although our interpretation of the social self perception subscale was the worst, it was almost in the upper zone of the interpreted level (8-14/28). These findings could be referred to the tough, overloaded curricula in the majority of medical schools. Similar to previous studies, these results indicate a need for the creation of a supportive environment, entertainment and refreshments with the availability of facilities for religious, sporting and cultural activities.

Also, a study conducted by Al-Hazimi et al. on three traditional and one innovative medical schools: King Abdul Aziz University (KAU), Umm Al-Qura University (UQU), Sanaa University (SU) and Dundee University (DU) reported the following mean scores for subscales: for Perceptions of learning 23, 25, 24, and 34 respectively versus 28.2 in our study, for Perceptions of course organizers 23, 24, 22, and 29 versus 25.9 in our study, for Academic self-perceptions 17, 18, 17, and 23 versus 19.3 in our study, for Perceptions of atmosphere 23, 25, 23, and 35 versus 26.3 in our study and for Social self-perceptions 14, 15, 14 , and 20 versus 14.2 in our study [17].

A gender difference has been noted in our study where female students' perception of the learning environment is more positive than that of males (overall DREEM mean score 114.5 for females versus 112.5 for males). Similar findings were seen in Dundee, large UK medical school (126 for females versus 123 for males) and Faculty of Medical Sciences, Trinidad (112.78 versus 105.39) $[20,22]$.

However, no statistically significant difference between males and females for the total score of DREEM was reported in our study. This might be attributed to that both sexes are equal in the learning process. This is in agreement to that reported by Till from Canada [22] but is contrary to that reported in a study carried out in Argentina in which a statistically significant difference between the sexes was found, with women in general more critical about the quality of teaching and the general climate of the school, especially in the areas of student participation in class and the authoritarian attitudes of teachers [13]. Also, a study in a large UK medical schools reported statistically significant results between both sexes [19].

The gender differences between results identified in our study compared to other studies can probably be attributed to curricular differences in our school which is generally student centered, based on integration where males and females are on equal foot in the learning process. On the other hand, in the comparative studies a more traditional didactic course is still taught. Also, male and female students are separated in learning sessions (in some countries especially Saudi Arabia), the latter often being taught via video-link

While taking the individual items into consideration, no single item scored more than 3.5 over 4 and this indicated, according to the practical guide of McAleer and Roff, that there was not real positive or particularly excellent aspect of the learning environment of our medical school [18].The majority of items' mean scores were between 2 and 3 and this indicated that they could be enhanced.

In our study, the three highest scored items were: item 1 (Students are encouraged to participate in teaching/learning sessions), which received a score of 2.89/4; item 49 (students feel able to ask the questions they want, with a score of 2.84/4; and item 2 (the course organizers are knowledgeable), with a score of $2.77 / 4$. These items revealed a safe and permissive environment fostered by PBL sessions. In contrast, in a study conducted in Iran, the three most highly scored items were: item 10 (I am confident about my passing this year), which received a score of 2.8; item 15 (I have good friends in this school), with a score of 2.8; and item 19 (my social life is good), with a score of 2.7. Their results highlighted a more care with the social environment [28].

There were 12 DREEM items that scored less than 2 . Out of the 12 items, 8 were negative (items with asterisk); 1 of them belonged to the students perception of learning subscale (The teaching over-emphasizes factual learning) , 3 of them belonged to students perception of course organizers subscale (These items highlighted that course organizers mock of the students, are dictatorial and get angry during teaching sessions). Another 3 items belonged to perception of atmosphere subscale and 1 item referred to social self-perception subscale (Students are too tired to enjoy the course). The remaining 4 items revealed that students are not able to recall all they needed, enjoyment outweighs the stress of the course, and support system is inappropriate, and tiring and boring feeling in the course of study.

These findings are particularly interesting because they contradict our school learning, innovative learning philosophies especially the over emphasis on factual learning, the inability to recall all that students need, and the dissatisfaction complaints items from our students. These 
entire problems should not be clearly apparent particularly in our school with student- centered and integrated system. So, all these 12 items need to be examined more closely as they reveal real problematic areas and require further review of both quantity and quality of our curricula.

\section{Self Assessment}

To the best our knowledge, this is the first reported study evaluating the learning environment in Egypt. The DREEM model was very diagnostic highlighting strengths and areas of concern in our school. Also, the sample size was representative to the six years of study and high response rate could add value.

Although the results of our study are the first indicators of how students perceive their learning environment, the present study offers no comparison with the expectation of students of their medical school learning environment and the correlation with academic achievements. It is well known that learning environment has a considerable effect on the approach of students to learning and their academic success. Thus, investigating the correlation between perception of learning environment and the academic success of students who participated in the study would be a good study to pursue.

Moreover, one of the most important limitations of the study is the use of a questionnaire to assess the perception of learning environment because there is the possibility of leaving out some components of a specific context. The results of this study, therefore, should be further supported by new studies especially if there will be a combination of qualitative techniques. This will permit enhancing the positive items and further investigating problematic areas and identifying their root causes.

\section{Conclusion}

The study concludes that students throughout the different years of study perceived the learning environment positively. Nevertheless, the study also revealed problematic areas in some items which enabled us to adopt some remedial measures. So, the DREEM questionnaire has been useful in identifying the strengths and limitations of the curriculum.

Considering all of the study's findings, we arrived at the following: overall assumptions concerning the learning environment of FOM SCU: overall, the faculty has a reasonably positive environment with ample room for improvement, The course organizers are knowledgeable and well prepared for sessions; but they are strict, and the course is overloaded by too much factual learning evidenced by inability of students to recall all they needed.; furthermore, an inefficient social support system and a cheating problem are clearly apparent. Finally students are experiencing a considerable amount of stress.

The study strongly recommends conducting the results to the relevant authorities utilizing them as basis for strategic planning and resource utilization. Results also should be used as guidance to institutional remedial action regarding students' indication of areas of concern.

\section{References}

1. Stenhouse L (1975) Introduction to curriculum research and development Heinemann, London, UK.

2. Genn JM (2001) AMEE Medical Education Guide No 23 (Part 1): Curriculum, environment, climate, quality and change in medical education-a unifying perspective. Med Teach 23: 337-344.
3. Wall D (2000) Educational concepts: the theory behind the practical aspects of teaching and learning. Teaching Made Easy: A manual for Health Professionals, Radcliffe Medical Press Ltd, Oxford, USA.

4. Talaat W, Hosney S, Abd-Allah E, Makhlouf L, Maklady F (1995) Problem based Learning, Priority health problems in problem-based learning: The Suez Canal Experience. Annals of Community-Oriented Education 8: 183-194.

5. Harden RM (1986) Ten questions to ask when planning a course or curriculum Med Educ 20: 356-365.

6. Bloom BS (1964) Stability and change in human characteristics. John Wiley \& Sons, New York, USA.

7. Pace CR, Stern G (1958) An approach to the measurement of the psychological characteristics of learning environments. Journal of Educational Psychology 49: $269-277$.

8. Genn JM, Harden RM (1986) What is medical education here really like? Suggestions for action research studies of climates of medical education environments. Med Teach 8: 111-124.

9. Genn JM (2001) AMEE Medical Education Guide No 23 (Part 2): Curriculum environment, climate, quality and change in medical education-a unifying perspective. Med Teach 23: 445-454.

10. Jamaiah I (2008) Review of research in learning environment. Journal of the University of Malaya Medical Centre 11: 7-11.

11. Soemantr D, Herrera C, Riquelme A (2010) Measuring the educationa environment in health professions studies: A systematic review. Med Teach 32: $947-952$

12. Roff S, Harden RM, Al-Qahtani M, Ahmed AU, Deza H, et al. (1997) Development and validation of the Dundee Ready Education Environment Measure (DREEM). Med Teach 19: 295-299.

13. Mayya S, Roff S (2004) Students' perceptions of educational environment: comparison of academic achievers and under-achievers at Kasturba Medical College, India. Educ Health 17: 280-291.

14. Roff S (2005) The Dundee Ready Educational Environment Measure (DREEM)-a generic instrument for measuring students' perceptions of undergraduate health professions curricula. Medical Teacher 27: 322-325.

15. Demirören M, Palaoglu O, Kemahli S, Özyurda F, Ayhan IH (2008) Perceptions of students in different phases of medical education of educational environment: Ankara University Faculty of Medicine. Med Educ Online 13: 1-8.

16. El-Hazimi A, Zaini R, Al-Hyiani AM, Hassan N, Gunaid A, et al. (2004) Educational environment in conventional and innovative medical schools: $A$ study in four undergraduate medical schools. Education for Health: Change in Learning and Practice 17: 192-203.

17. Mcaleer S, Roff S (2002) A practical guide to using the Dundee Ready Education Measure (DREEM). AMEE Medical Education Guide No.23 Curriculum, environment, climate, quality and change in medical education; a unifying perspective. Association of Medical Education in Europe, Dundee, UK

18. Bassaw B, Roff S, McAleer S, Roopnarinesing S, Lisle JD, et al. (2003) Students' perspectives on the educational environment, Faculty of Medical Sciences, Trinidad. Med Teach 25: 522-526.

19. Jiffry MTM, McAleer S, Fernandoo S, Marasinghe RB (2005) Using the DREEM questionnaire to gather baseline information on an evolving medical school in Sri Lanka. Med Teach 27: 348-352.

20. Al-Qahtani MF (1999) Approaches to study and learning environment in medical schools with special reference to the gulf countries. PhD thesis, Faculty of Medicine, Dentistry and Nursing, University of Dundee, UK

21. Dunne F, Mcaleer S, Roff S (2006) Assessment of the undergraduate medical education environment in a large UK medical school. Health Educ J 65: 149 158

22. Al-Ayed IH, Sheik SA (2008) Assessment of the educational environment at the College of Medicine of King Saud University, Riyadh. Eastern Mediterranean Health Journal 14: 953-959.

23. Till $H$ (2004) Identifying the perceived weaknesses of a new curriculum by means of the Dundee Ready Education Environment Measure (DREEM) Inventory. Med Teach 26: 39-45.

24. Roff S, McAleer S, Ifere OS, Bhattacharya S (2001) A global diagnostic too for measuring educational environment: comparing Nigeria and Nepal. Med Teach 23: 378-382. 
Citation: Youssef WT, Wazir YME, Ghaly MS, Khadragy RAE (2013) Evaluation of the Learning Environment at the Faculty of Medicine, Suez Canal University: Students' Perceptions. Intel Prop Rights 1: 102. doi:10.4172/2375-4516.1000102

Page 7 of 7

25. Varma R, Tiyagi E, Gupta JK (2005) Determining the quality of educational climate across multiple undergraduate teaching sites using the DREEM inventory. BMC Med Educ 5: 8.

26. Miles S, Leinster SJ (2007) Medical students' perceptions of their educational environment: expected versus actual perceptions. Med Educ 41: 265-272.

27. Al Hazmi A, Al Hyiani A, Roff S (2004) Perceptions of the educational environment of the medical school in King Abdul Aziz University, Saudi Arabia. Med teach 26: 570-573.

28. Aghamolaei T, Fazel I (2010) Medical students' perceptions of the educationa environment at an Iranian Medical Sciences University. BMC Med Educ 10: $87-98$. 